\title{
Pengaruh Refugia Bunga Telekan (Tagetes erecta) dan Bunga Kertas (Zinnia elegans) pada Populasi Artropoda dan Hasil Tanaman Padi
}

\section{(The Effect of Refugia Plant Tagetes erecta and Zinnia elegans on Arthropod Populations and Paddy Crop Yields)}

\author{
Nur Azizah', Yugi Rahayu Ahadiyat ${ }^{1}$, Noor Farid ${ }^{2}$, Okti Herliana ${ }^{1 \star}$
}

(Diterima September 2021/Disetjui Januari 2022)

\begin{abstract}
ABSTRAK
Penelitian ini bertujuan mengevaluasi pengaruh dua tanaman refugia bunga telekan (Tagetes erecta)dan bunga kertas (Zinnia elegans) pada kelimpahan relatif yang dominan dan diversitas artropoda sertapada hasil tanaman padi. Artropoda diamati dengan metode visual control pada setiap fase pertumbuhanpadi. Hama dan musuh alami diamati selama 15 menit di 5 plot sawah dan 1 blok refugia pada 3 waktu (pukul 08.00-10.00, 12.00-14.00, dan 15.00-17.00) dengan jarak pengamatan 2 meter. Ciri-ciri morfologi diamati untuk diidentifikasi sampai tingkat spesies dan dikelompokkan sesuai dengan relung ekologisnya. Kelimpahan nisbi dan indeks diversitas Shannon dihitung. Data pertumbuhan dan komponen hasil tanaman padi dianalisis dengan uji $\mathrm{F}$ atau analisis varian dilanjutkan dengan uji jarak berganda Duncan apabila terdapat perbedaan yang nyata. Kelimpahan artropoda yang ditemukanberjumlah 3.411 individu yang terdiri atas 8 ordo, yaitu Diptera, Aranae, Odonota, Hymenoptera, Orthoptera, Coleoptera, Hemiptera, dan Lepidoptera dengan 44 famili serta total 71 spesies. Kelimpahannisbi artropoda dominan di lahan yang ditanami bunga kertas ialah semut merah (11,07\%), walang sangit (38,37\%), dan kupu-kupu (Hypolimnas bolina) $(0,17 \%)$, dengan nilai indeks keanekaragaman spesies berturut-turut 3,25\%; 2,94\%, dan $2,56 \%$. Kelimpahan relatif artropoda dominan di lahan yang ditanami bunga telekan ialah musuh alami serangga Cardiochiles Cardiochiles philippinensis $(8,84 \%)$, belalang hijau $(25,45 \%)$, dan penggerek batang padi kuning $(0,34 \%)$, dengan nilai indeks keanekaragaman tergolong sedang. Penanaman bunga telekan memberi hasil padi yang setara dengan perlakuan kontrolberturut-turut $8,10 \mathrm{t} / \mathrm{ha}$ dan $7,60 \mathrm{t} / \mathrm{ha}$, sedangkan lahan yang ditanami bunga kertas menghasilkan padi 6,30 t/ha.
\end{abstract}

Kata kunci: hasil padi, kelimpahan dan diversitas arthropoda, Tagetes erecta, Zinnia elegans

\section{ABSTRACT}

This study aimed to determine the effect of refugia (Tagetes erecta and Zinnia elegans) plants on therelative abundance and diversity of Arthropod's dominance in the rice plant area and on rice yield. The Arthropods were observed by the visual control method at each rice growth stage. Observations were made during 15 minutes in five plots of rice area and one refugium block at three different times $(08.00-10.00,12.00-14.00$, and 15.00-17.00. The morphological features were identified and recorded toidentify the species level and grouped according to their ecological niches. The relative abundance andShannon Diversity Index were calculated. The rice plants' growth data and yield components were analyzed by ANOVA followed by DMRT if there were any significant differences among the treatments. Relative abundance of dominant arthropods on rice land planted with Zinnia elegans was Solenopsis geminata $(11.07 \%)$, Leptocorisa oratorius (38.37\%), and Hypolimnas bolina $(0.17 \%)$ with species diversityindex values of $3.25 \% ; 2.94 \%$, and $2.56 \%$, respectively. In contrast, the relative abundance of arthropodsin rice land planted with Tagetes erecta were Cardiochiles philippinensis (8.84\%), Oxya chinensis $(25.45 \%)$, and Scirpophaga incertulas $(0.34 \%)$ with moderate diversity index values. The Tagetes erecta gave an equivalent result of rice yield with the control, namely $8,10 \mathrm{t} / \mathrm{ha}$ and 7,60 t/ha, respectively, whilethe Zinnia elegans offers rice yield of $6,30 \mathrm{t} / \mathrm{ha}$.

Keywords: arthropod diversity, paddy yield, Tagetes erecta L, Zinnia elegans

\section{PENDAHULUAN}

Padi merupakan serealia utama yang dihasilkan dan dikonsumsi oleh $90 \%$ masyarakat Asia

1 Laboratorium Agroekologi, Jurusan Agroteknologi, Fakultas Pertanian, Universitas Jenderal Soedirman, Jl. Prof. Dr. HR. Boenjamin 708, Purwokerto 53122

2 Laboratorium Pemuliaan Tanaman dan Bioteknologi, Jurusan Agroteknologi, Fakultas Pertanian, Universitas Jenderal Soedirman, Jl. Prof. Dr. HR. Boenjamin 708, Purwokerto 53122

* Penulis Korespondensi: Email: okti.herliana@unsoed.ac.id
(Parasappa et al. 2017). Kebutuhan beras sebagai salah satu sumber pangan utama meningkat seiring dengan jumlah penduduk Indonesia yang terus bertambah dengan laju pertumbuhan penduduk 2,31\% per tahun. Konsumsi rumah tangga berbahan dasar beras antara tahun 1993 dan tahun 2015 mencapai $7,85 \mathrm{~kg} / \mathrm{kapita} / \mathrm{tahun}$ atau tumbuh $70,86 \%$ per tahun (Badan Pusat Statistik 2017). Menurut Sari dan Bagyo (2014), tingginya jumlah penduduk Indonesia yang terus berkembangmenjadi salah satu kendala dalam pemenuhan kebutuhan pangan di Indonesia. Upaya 
peningkatan produktivitas padi juga masih terdapat kendala di antaranya adalah serangan hama. Hama utama yang menyerang tanaman padi di antaranya adalah wereng cokelat dan penggerek batang padi. Beberapa hama lainnya yang berpotensi merusak pertanaman padi adalah wereng punggung putih, wereng hijau, lembing batu, ulat grayak, pelipat daun, dan walang sangit (Effendi 2009). Rata-rata kehilangan hasil produksi pertanian karena serangan organisme pengganggu tanaman (OPT) $\pm 30 \%$ dari potensi hasil, dan kehilangan hasil karena hama sekitar 20-25\% (Usyati 2018). Hal tersebut mendorong petani mengendalikannya dengan pestisida.

Penggunaan pestisida secara intensif berhasil memacu produksi padi tetapi berdampak negatif, di antaranya berbahaya bagi kesehatan petani, masyarakat, dan makhluk hidup lainnya. Pemakaianpestisida secara terus menerus juga berdampak pada tingginya biaya produksi bagi petani dan dapat membunuh organisme yang bermanfaat sebagai musuh alami hama tanaman padi (Sakir 2018). Aplikasi pestisida sintetik dapat menimbulkan masalah lingkungan (Visalakhsmi 2014), seperti ketidakseimbangan rantai sistem di lahan pertanian justru menyebabkan populasi hama meningkat, akumulasi pada hasil panen, resistensi hama, berkurangnya musuh alami, dan resurgensi hama. Ekosistem yang terganggu dan aplikasi pestisida menurunkan diversitas artropoda. Aplikasi pestisida dapat menyebabkan hama dan serangga nontarget melemah dan mati, di antaranya dari golongan artropoda. Penurunan kelimpahan dan diversitas artropoda tersebut berpengaruh pada peran artropoda sehingga siklus perubahan materi menjadi terhambat (Wardani et al. 2013).

Setiap jenis hama secara alami dikendalikan oleh kompleks musuh alami yang meliputi predator, parasitoid, dan patogen hama. Predator dan parasitoid tersebut berperan membantu mengendalikanpopulasi serangga hama tanaman padi. Menurut Mustakim et al. (2014), upaya untuk meningkatkan keanekaragaman musuh alami adalah dengan menciptakan mikrohabitat di areal pertanian. Salah satunya ialah dengan memanfaatkan tumbuhan lain di sekitar lahan pertanian (Altieri \& Letourneau1982) yang bermanfaat bagi tanaman padi meningkatkan keanekaragaman habitat dan menghasilkan nektar yang dijadikan sebagai sumber pakan (Sari \& Yanuwiadi 2014). Tanaman refugia merupakan tanaman berbunga yang menjadi habitat bagi serangga karena mampu menyediakan makanan yang dibutuhkan serangga berupa nektar dan madu. Keberadaan musuh alami dapat ditingkatkan dengan menyediakan habitat dan sumber makanan untuk kelangsungan hidupnya sehingga tanaman refugia di sekitar pertanaman menjadi habitat alternatif predator dan parasitoid (Sumini \& Bahri 2020). Refugia dapat berupa tanaman bunga yang berwarna yang mendukung kegiatan konservasi sebagai pilihan dalam menjaga agroekosistem pada lahan pertanian(Allifah et al. 2013).
Hasil penelitian menunjukkan bahwa kombinasi tumbuhan famili Asteraceae terbukti efektif menarik kumbang koksi (Coccinella septempunctata) dengan persentase ketertarikan 50\% (Sari \& Bagyo 2014). Hasil penelitian Allifah et al. (2013) menunjukkan bahwa lahan dengan tanaman refugia mampu menarik musuh alami dalam jumlah yang lebih tinggi dibandingkan tanpa refugia dengan kelimpahan rata-rata musuh alami pada lahan dengan tanaman refugia sebesar $5,16 \%$ sedangkan pada lahan tanpa aplikasi tanaman refugia hanya $3,45 \%$. Tanaman refugia dapat mendukung kegiatan konservasi dalam menjaga keseimbangan agroekosistem di lahan pertanian. Warna tanaman refugia mampu mendatangkan musuh alami dan menjadi mikrohabitatnya (Kurniawati \& Martono 2015). Selain ketertarikan pada warna, ketersediaan kandungan nektar dan kondisi bunga refugia juga memengaruhi keanekaragaman dan kelimpahan musuh alami (Rahardjo et al. 2018). Bunga telekan (Tagetes erecta) dan bunga kertas (Zinnia elegans) termasuk jenis tanaman yang berwarna mencolok seperti jingga dan merah, serta aroma yang menarik perhatian serangga. Penelitian ini bertujuan mengevaluasi pengaruh tanaman refugia bunga telekan dan bungakertas pada kelimpahan relatif dan diversitas artropoda serta hasil tanaman padi.

\section{METODE PENELITIAN}

Penelitian ini dilaksanakan di lahan sawah Desa Adipala, Kecamatan Adipala, Kabupaten Cilacap. Artropoda diidentifikasi dan data dianalisis di Laboratorium Agroekologi, Fakultas Pertanian, Universitas Jenderal Soedirman, Purwokerto, mulai bulan November 2017 hingga Februari 2018. Bahan penelitian ialah benih padi varietas Ciherang (PT ASA), bibit bunga telekan, bibit bunga kertas, pupuk organik (Pertoganik PT Pupuk Indonesia (Persero) Group), pupuk kimia (urea dan phonska PT Petrokimia Gresik), dan pestisida (Gandasil D PT Kalatham, Nurelle D 500/50 EC PT Dow Agrosciences, Antracol PT Bayer). Alat yang digunakan antara lain moisture meter OSK 8085 (Kett,Ogawa Seiki-Japan), dan kunci determinasi serangga.

Artropoda diamati secara visual control pada setiap fase pertumbuhan padi. Pada metode ini, serangga yang mengunjungi rumpun padi diamati langsung dari jarak jauh, dengan jarak pengamatan per 2 meter, pada waktu-waktu tertentu (Addina et al. 2013). Setiap fase diamati selama 15 menit pada 3 waktu (pukul 08.00-10.00, 12.00-14.00, dan 15.00-17.00). Artropoda yang diamatiialah hama dan musuh alami.

Ciri-ciri morfologi artropoda diamati untuk diidentifikasi sampai tingkat spesies dan dikelompokkan sesuai dengan relung ekologisnya, kemudian dihitung kelimpahan relatif dan indeks diversitas Shannon $\left(H^{\prime}\right)$. Data pertumbuhan (tinggi tanaman, jumlah anakan, jumlah malai produktif per rumpun, bobot kering akar, bobot kering tajuk) dan komponen hasil tanaman padi 
(jumlah biji isi per rumpun,bobot hampa per rumpun, bobot isi per rumpun bobot 1000 biji, dan hasil ton per hektar) dianalisis dengan Analisis Varians dan dilanjutkan dengan uji jarak berganda Duncan pada tingkat kepercayaan $95 \%$ apabila terdapat perbedaan yang nyata.

\section{HASIL DAN PEMBAHASAN}

Kelimpahan Relatif Artropoda pada Setiap Fase Pertumbuhan Padi berdasarkan Perannya dalam Ekosistem Kelimpahan artropoda yang ditemukan dalam penelitian ini seluruhnya berjumlah 3.411 individu, terdiri atas 8 ordo, yaitu Diptera, Aranae, Odonota, Hymenoptera, Orthoptera, Coleoptera, Hemiptera, dan Lepidoptera, dengan 44 famili serta total 71 spesies (Tabel 1). Kelimpahan relatif artropoda pada fase vegetatif tertinggi terdapat pada peran predator (Tabel 2) dan terletak pada petak perlakuan penerapan tanaman refugia. Kelimpahan relatif artropoda yang berperan sebagai hama tertinggi pada petak perlakuan kontrol dan kelimpahan relatif artropoda musuh alami (predator, parasitoid, dan polinator) adalah yang terendah. Hal ini karena aplikasi pestisida sintetik pada petak kontrol menurunkan kelimpahan artropoda musuh alami, sedangkan pada petak penerapan refugia tidak ada aplikasi pestisida sintetik. Menurut Kartohardjono (2011), aplikasi insektisida atau pestisida efektif mengendalikan hama secara parsial tetapi secara bersamaan juga membunuh musuh alami sebagaiagen pengendali hama.

Fase vegetatif didominasi oleh predator pada 3 perlakuan (aplikasi pestisida, tanaman bunga telekan, dan tanaman bunga kertas). Refugia mendukung perubahan komposisi artropoda yang berdampak pada penurunan proporsi herbivora. Hal ini karena predator dan parasitoid bermanfaat yang dapat menekan populasi herbivora. Beberapa penelitian pada ekosistem pertanian menunjukkan bahwa peningkatan keanekaragaman predator artropoda dan parasitoid

Tabel 1 Total ordo, famili, spesies, dan individu pada setiap perlakuan

\begin{tabular}{llll}
\hline \multirow{2}{*}{ Total } & \multicolumn{3}{c}{ Perlakuan } \\
\cline { 2 - 4 } & Kontrol & $\begin{array}{c}\text { Zinnia } \\
\text { elegans }\end{array}$ & Tagetes erecta \\
\hline Ordo & 8 & 8 & 8 \\
Famili & 33 & 37 & 33 \\
Spesies & 43 & 59 & 51 \\
Individu & 1086 & 1453 & 872 \\
\hline
\end{tabular}

dapat memengaruhi tingkat konsumsi mangsa (Lopes et al. 2017). Kelimpahan artropoda tertinggi pada fase reproduktif dan pemasakan terdapat pada artropoda hama yang terletak pada petak yang ditanami refugia. Hama yang dominan pada kedua fase ini di petak yang ditanami refugia ialah walang sangit (Leptocorisa oratorius). Menurut Tridiptasari (2017), walang sangit merupakan hama utama dari ordo Hemiptera yang merusak tanaman padi dengan cara mengisap bulir padi pada fase reproduktif dan pemasakan dengan tipe mulut penusuk pengisapnya sehingga bulir menjadi hampa. Tingginya hama walang sangit menurut Triyono (2017) ialah karena padi merupakan makanan utama hama tersebut. Selain itu, suhu di lingkungan mendukung, yakni $29-30^{\circ} \mathrm{C}$. Suhu rata-rata pada fase generatif dan reproduktif saat penelitian ini ialah $27,57^{\circ} \mathrm{C}$ dan $27,4^{\circ} \mathrm{C}$. Hal ini sesuai dengan pendapat Arifin (2012), bahwa suhu optimum untuk perkembangbiakan hama ini ialah $27-30^{\circ} \mathrm{C}$. Kelem-bapan tanah, udara, dan tempat hidup serangga juga merupakan faktor yang dapat memengaruhi persebaran, aktivitas, dan perkembangan serangga. Kelembapan akan memengaruhi penguapan cairan tubuh serangga, dan juga preferensi serangga untuk hidup, serta tambahan tempat persembunyian aktivitas serangga sering sangat dipengaruhi oleh respons terhadap cahaya (Abidin 2020).

\section{Kelimpahan Relatif Jenis Artropoda Musuh Alami Dominan, Hama Dominan, dan Hama Terendah pada Setiap Fase Pertumbuhan Padi}

Kelimpahan relatif adalah persentase komposisi suatu organisme dari jenis tertentu relatif terhadap jumlah total organisme di daerah tersebut. Dominasi adalah tingginya populasi satu spesies dibandingkan dengan spesies lainnya yang terdapat dalam suatu areal.

Berdasarkan Tabel 3, jenis artropoda musuh alami dan hama dominan serta hama terendah di lahan sawah penerapan refugia bunga kertas pada fase vegetatif berturut-turut ialah semut merah (Solenopsis geminata), kupu-kupu cokelat (Melanitis leda), dan hama kepinding tanah (Scotinophora coarctata). Kemudian, pada fase reproduktif jenis artropoda musuh alami dan hama dominan serta hama terendah berbeda, ialah laba-laba rahang panjang (Tetragnatha maxillosa), walang sangit (Leptocorisa oratorius), dan belalang kukus hijau (Atractomorpha crenulata). Labalaba rahang panjang dan walang sangit tetap sebagai musuh alami dominan dan hama dominan pada fase pemasakan. Memasuki fase pemasakan, hama teren-

Tabel 2 Kelimpahan relatif artropoda berdasarkan perannya pada setiap fase pertumbuhan padi

\begin{tabular}{|c|c|c|c|c|c|c|c|c|c|}
\hline KR (\%) & \multicolumn{3}{|c|}{ Vegetatif } & \multicolumn{3}{|c|}{ Reproduktif } & \multicolumn{3}{|c|}{ Pemasakan } \\
\hline Peran & $\mathrm{K}$ & R1 & $\mathrm{R} 2$ & $\mathrm{~K}$ & R1 & R2 & $\mathrm{K}$ & R1 & R2 \\
\hline Netral & 12,27 & 0,41 & 0,54 & 12,39 & 0,00 & 0,89 & 8,00 & 0,17 & 0,34 \\
\hline Parasitoid & 2,42 & 17.82 & 4.80 & 26.93 & 15.94 & 1.34 & 43,86 & 4,41 & 17.68 \\
\hline Predator & 36,22 & 49,40 & 45,40 & 28,63 & 32,73 & 29,47 & 17,51 & 18,85 & 15,65 \\
\hline Polinator & 0.20 & 2.26 & 11.04 & 0.00 & 1.53 & 5.80 & 0,54 & 1.70 & 4,43 \\
\hline Hama & 48,90 & 30,12 & 38,42 & 32,05 & 49,12 & 62,50 & 21,46 & 74,87 & 61,90 \\
\hline
\end{tabular}

Keterangan: $\mathrm{KR}(\%)=$ kelimpahan relatif, $\mathrm{K}=$ kontrol, $\mathrm{R} 1$ = perlakuan bunga kertas, dan $\mathrm{R} 2$ = perlakuan bunga telekan . 
dah berbeda dengan pada kedua fase sebelumnya, yaitu ulat jengkal (Hyposidra talaca). Menurut Sunariah et al. (2016), laba-laba rahang panjang merupakan spesies dari famili Tetragnathidae yang berperan sebagai predator. Famili ini merupakan kelompok labalaba yang aktif di tajuk tanaman padi, membuat jaring pada pelepah daun karena laba-laba tersebut menunggu mangsa di dalam jaring dan sering berada di dalam tajuk tanaman padi.

Jenis artropoda musuh alami dan hama paling dominan serta hama terendah di lahan sawah penerapan refugia tanaman telekan pada fase vegetatif berturut-turut ialah walang sangit, belalang hijau (Oxya chinensis), dan penggerek batang padi kuning (Scirpophaga incertulas) (Tabel 4). Kemudian, pada fase reproduktif jenis artropoda hama dominan dan terendah berturut-turut sama seperti pada fase vegetatif. Musuh alami dominan pada fase reproduktif ialah capung badak (Ortherum sabina). Jenis arthropoda musuh alami dominan dan hama dominan pada fase pemasakan, berbeda dari dua fase sebelumnya, yaitu musuh alami serangga Cardiochiles dan walang sangit. Pada fase pemasakan ini penggerek batang padi kuning tetap sebagai hama terendah. Berdasarkan Tabel 3, kelimpahan relatif penggerek batang padi kuning dari fase vegetatif sampai pemasakan menurun, yaitu $0,54 \%, 0,45 \%$, dan $0,34 \%$. Hal ini diduga karena keberadaan hama penggerek batang tersebut dapat ditekan oleh keberadaan musuh alami yang ada. Menurut Adiartayasa dan Wijaya (2016), musuh alami penggerek batang padi kuning ialah predator dan parasitoid.

\section{Keanekaragaman Spesies Artropoda pada Pertanaman Padi di Sawah Berdasarkan Fase Pertumbuhan Padi}

Keanekaragaman spesies artropoda pada setiap fase pertumbuhan padi tergolong sedang $\left(H^{\prime}=1-3\right)$ kecuali pada fase vegetatif di petak perlakuan refugia bunga kertas yang menunjukkan keanekaragaman tinggi $\left(H^{\prime}>3\right)$, yaitu 3,25 (Gambar 1). Keanekaragaman spesies artropoda pada setiap fase di kedua petak perlakuan refugia lebih tinggi dibandingkan di petak kontrol. Penerapan refugia bunga kertas menunjukkan keanekaragaman spesies artropoda tertinggi jika dibandingkan dengan kontrol dan penerapan refugia bunga telekan, kecuali pada fase pemasakan; keanekaragaman spesies artropoda tertinggi pada penerapan refugia bunga telekan, yaitu $2,79 \%$. Hal ini karena pada penerapan tanaman refugia tidak menggunakan aplikasi pestisida sintetik, sedangkan pada kontrol menggunakan aplikasi pestisida sintetik dan tanpa refugia. Menurut Khodijah (2013), pengurangan penggunaan pestisida sintetik pada lahan pertanian dapat melindungi keanekaragaman hayati. Selain itu penambahan tanaman berbunga pada lahan pertanian dapat meningkatkan kedatangan serangga baik itu serangga herbivora maupun musuh alami (Kurniawati 2015). Populasi artropoda tertinggi terdapat pada lahan padi sawah dengan aplikasi refugia, dengan tumbuhan liar adalah habitat dan

Tabel 3 Kelimpahan relatif jenis artropoda musuh alami dominan, hama dominan, dan hama terendah pada setiap fase pertumbuhan padi

\begin{tabular}{|c|c|c|c|c|c|c|c|c|c|}
\hline \multirow{2}{*}{ Perlakuan } & \multicolumn{3}{|c|}{ Vegetatif } & \multicolumn{3}{|c|}{ Reproduktif } & \multicolumn{3}{|c|}{ Pemasakan } \\
\hline & MD (\%) & HD (\%) & $\mathrm{HR}(\%)$ & MD (\%) & HD (\%) & HR (\%) & MD (\%) & $\mathrm{HD}(\%)$ & HR (\%) \\
\hline \multirow[t]{3}{*}{$\mathrm{K}$} & U 18,11 & Sc 25,50 & Sco 0,40 & Ca 26,07 & Sc 18,80 & Cn 0,85 & $\mathrm{Ca} 38,03$ & Cn 11,83 & Sco 0,28 \\
\hline & Or 5,63 & Cn 9,66 & $\mathrm{H} 0,40$ & U 14,53 & M 5,98 & L 0,43 & U 6,20 & Sc 7,32 & Och 0,28 \\
\hline & 13,42 & Oxy 7,04 & $\mathrm{Ph} 0,20$ & Or 3,42 & P 3,42 & Mi 0,43 & Ar 4,23 & L 1,95 & Sp 0,28 \\
\hline \multirow[t]{3}{*}{$\mathrm{R} 1$} & S 11,07 & M 7,58 & Sco 0,20 & T 5,85 & Le 14,63 & At 0,53 & T 4,07 & Le 38,37 & Hy 0,17 \\
\hline & C 7,58 & L 5,33 & Le 0,20 & Co 5,05 & Cn 9,57 & Sco 0,27 & Or 3,23 & Cn 12,73 & Pie 0,17 \\
\hline & $O \times 6,15$ & P 5,12 & Ci 0,20 & Cn 5,05 & P 5,85 & Hy 0,27 & Co 3,06 & N 6,45 & Ph 0,17 \\
\hline \multirow[t]{3}{*}{$\mathrm{R} 2$} & T 8,67 & Oxy 17,52 & Sc 0,54 & Or 7,14 & Oxy 25,45 & Au 0,45 & Ca 8,84 & Le 23,13 & Te 0,34 \\
\hline & Or 7,32 & L 10,57 & Sco 0,27 & T 5,80 & L 15,18 & Sc 0,45 & Or 5,10 & Oxy 17,69 & Sc 0,34 \\
\hline & $O \times 6,50$ & M 5,15 & $\mathrm{H} 0,27$ & U 3,57 & M 8,04 & Ce 0,45 & T 4,76 & $\mathrm{~N} 4,76$ & Ce 0,34 \\
\hline
\end{tabular}

Keterangan: $\mathrm{MD}=$ musuh alami dominan, $\mathrm{HD}=$ hama dominan, $\mathrm{HR}=$ hama terendah, $\mathrm{U}=$ Aranae $($ Undiscribe), $\mathrm{S}=$ Solenopsis geminata, $\mathrm{T}=$ Tetragnatha maxillosa, $\mathrm{Sc}=$ Scirpophaga incertulas, $\mathrm{Cn}=$ Cnaphalocrosis medinalis, Oxy = Oxya chinensis, $\mathrm{M}=$ Melanitis leda, $\mathrm{Sco}=$ Scotinophora coarctata, $\mathrm{Ca}=$ Cardiochiles philippinensis, At = Atractomorpha crenulata, $\mathrm{Hy}=$ Hyposidra talaca, $\mathrm{Or}=$ Ortherum sabina, Le $=$ Leptocorisa oratorius.

Tabel 4 Kelimpahan relatif jenis artropoda musuh alami paling dominan, hama paling dominan, dan hama terendah pada setiap fase pertumbuhan padi

\begin{tabular}{|c|c|c|c|c|c|c|c|c|c|}
\hline \multirow{2}{*}{ Perlakuan } & \multicolumn{3}{|c|}{ Vegetatif } & \multicolumn{3}{|c|}{ Reproduktif } & \multicolumn{3}{|c|}{ Pemasakan } \\
\hline & MD (\%) & HD (\%) & $\mathrm{HR}(\%)$ & MD (\%) & HD (\%) & HR (\%) & MD (\%) & HD (\%) & $\mathrm{HR}(\%)$ \\
\hline $\mathrm{K}$ & U 18,11 & Sc 25,50 & Sco 0,40 & Ca 26,07 & Sc 18,80 & Cn 0,85 & Ca 38,03 & Cn 11,83 & Sco 0,28 \\
\hline R1 & S 11,07 & M 7,58 & Sco 0,20 & T 5,85 & Le 14,63 & At 0,53 & T 4,07 & Le 38,37 & Нy 0,17 \\
\hline $\mathrm{R} 2$ & T 8,67 & Oxy 17,52 & Sc 0,54 & Or 7,14 & Oxy 25,45 & Sc 0,45 & Ca 8,84 & Le 23,13 & Te 0,34 \\
\hline
\end{tabular}

Keterangan: $\mathrm{MD}=$ musuh alami dominan, $\mathrm{HD}=$ hama dominan, $\mathrm{HR}=$ hama terendah, $\mathrm{U}=$ Aranae $($ Undiscribe), $\mathrm{S}=$ Solenopsis geminata, $\mathrm{T}=$ Tetragnatha maxillosa, $\mathrm{Sc}=$ Scirpophaga incertulas, $\mathrm{C} \mathrm{n}=$ Cnaphalocrosis medinalis, Oxy = Oxya chinensis, M = Melanitis leda, Sco = Scotinophora coarctata, $\mathrm{Ca}=$ Cardiochiles philippinensis, At $=$ Atractomorpha crenulata, $\mathrm{Hy}=$ Hyposidra talaca, $\mathrm{Or}=$ Ortherum sabina, $\mathrm{Le}=$ Leptocorisa oratorius. 
relung yang paling tepat untuk artropoda predator (Abidin 2020).

\section{Pengaruh Tanaman Refugia pada Pertumbuhan dan Hasil Padi \\ Aplikasi pestisida sintetik, refugia bunga telekan} dan bunga kertas berpengaruh beragam pada petumbuhan dan hasil padi. Berdasarkan hasil analisis varians (Tabel 5), berbagai perlakuan yang diberikan, yakni kontrol, penerapan bunga telekan, dan bunga kertas, tidak berbeda nyata pada variabel tinggi tanaman, jumlah malai produktif per rumpun, jumlah biji isi per rumpun, dan bobot 1000 biji. Penerapan bunga telekan menunjukkan hasil tertinggi dan berbeda nyata dengan kontrol dan refugia bunga kertas pada variabel bobot kering akar, bobot kering tajuk, bobot biji isi per rumpun, dan bobot gabah per hektar, yang setara dengan kontrol. Variabel jumlah anakan dan bobot biji hampa per rumpun pada penerapan bunga telekan memberikan hasil terbaik. Hal ini diduga karena kelimpahan musuh alami yang tertarik pada bunga telekan cukup tinggi sehingga dapat menekan populasi hama selama masa pertumbuhan padi sampai panen. Menurut Meyer (2006), kebanyakanserangga memiliki dua tipe penglihatan seperti pigmen yang dapat menyerap warna kuning terang, warna hijau, dan pigmen yang dapat menyerap warna merah muda dan sinar ultraviolet. Serangga yang tertarik pada warna merah biasanya lebah, dan warna kuning dapat menarik serangga lalat buah (Syafrizal 2016).

Hasil panen padi menunjukkan bahwa penggunaan tanaman refugia bunga telekan yang berwarna kuning (Gambar 2) mampu menghasilkan hasil panen tertinggi dibandingkan dengan kontrol dan refugia bunga kertas (Gambar 3). Warna kuning mampu mengalihkan perhatian hama target yang dapat mengganggu partumbuhan tanaman padi dibanding dengan penggunaan pestisida, di samping itu menurut Adawiyah et al. (2020), aplikasi insektisida yang berlebihan dan tidak tepat akan berdampak negatif pada perkembangan ekosistem dan lingkungan, mematikan serangga nontarget pestisida, dan mematikan musuh alami dan serangga bermanfaat seperti serangga penyerbuk. Pernyataan ini diperkuat oleh Muhibah \& Leksono (2015), bahwa aplikasi pestisida dapat menyebabkan mikroorganisme tanah berkurang sehingga secara keseluruhan mengakibatkan kesuburan lahan berkurang dan tanah mengeras, sehingga penanaman refugia menjadi alternatif pengendalian hama tanaman padi secara hayati yang dapat menjadi habitat musuh alami, karena berpengaruh pada biodiversitas dan kelimpahan serangga (Heong et al. 2014).

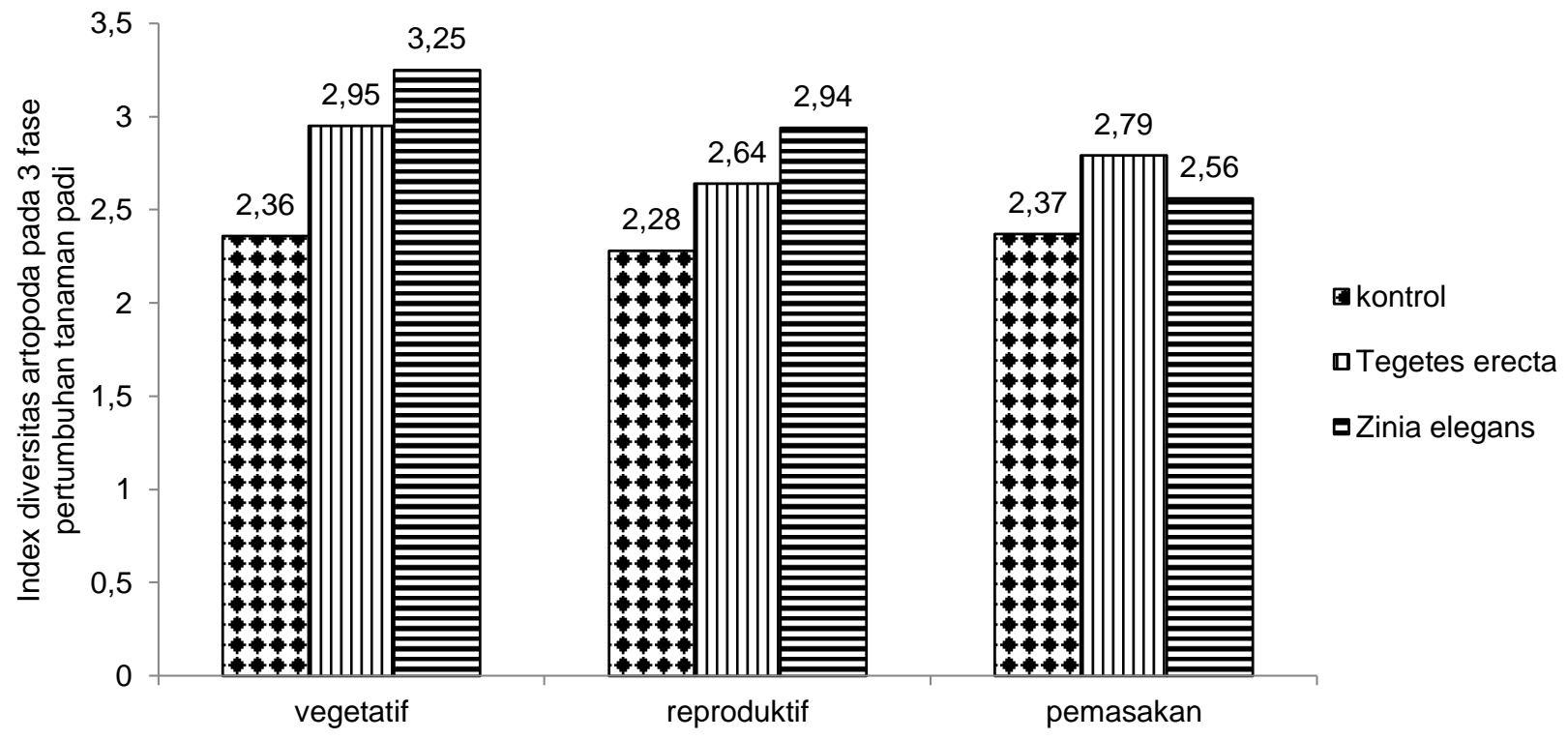

Gambar 1 Keanekaragaman spesies artropoda pada pertanaman padi di sawah berdasarkan fase pertumbuhan padi dengan perlakuan kontrol, refugia bunga telekan dan bunga kertas.

Tabel 5 Pengaruh perlakuan tanaman refugia dan penyemprotan pestisida pada pertumbuhan dan hasil padi

\begin{tabular}{ccccccccccc}
\hline Perlakuan & $\begin{array}{c}\text { TT } \\
(\mathrm{cm})\end{array}$ & JA & JMR & BKA $(\mathrm{g})$ & BKT $(\mathrm{g})$ & JBR & BHR $(\mathrm{g})$ & BIR $(\mathrm{g})$ & $\begin{array}{c}\text { BSB } \\
(\mathrm{g})\end{array}$ & $\begin{array}{c}\text { Hasil } \\
(\mathrm{t} / \mathrm{ha})\end{array}$ \\
\hline $\mathrm{K}$ & 37,85 & $20,30 \mathrm{a}$ & 20,70 & $3,38 \mathrm{~b}$ & $7,79 \mathrm{~b}$ & 9,12 & $1,50 \mathrm{a}$ & $59,61 \mathrm{~b}$ & 29,65 & $7,60 \mathrm{~b}$ \\
$\mathrm{R} 1$ & 36,60 & $20,20 \mathrm{a}$ & 20,30 & $1,99 \mathrm{a}$ & $5,45 \mathrm{a}$ & 8,22 & $1,47 \mathrm{a}$ & $49,41 \mathrm{a}$ & 27,87 & $6,30 \mathrm{a}$ \\
$\mathrm{R} 2$ & 35,85 & $29,40 \mathrm{~b}$ & 25,40 & $3,21 \mathrm{~b}$ & $7,24 \mathrm{~b}$ & 8,57 & $2,53 \mathrm{~b}$ & $63,51 \mathrm{~b}$ & 27,33 & $8,10 \mathrm{~b}$ \\
\hline KK $(\%)$ & 7,29 & 20,74 & 21,10 & 20,90 & 12,15 & 14,23 & 20,81 & 12,02 & 7,63 & 12,02 \\
\hline
\end{tabular}

Keterangan: TT = tinggi tanaman, JA = jumlah anakan, JMR = jumlah malai produktif per rumpun, BKA = bobot kering akar, $\mathrm{BKT}=$ bobot kering tajuk, JBR $=$ jumlah biji isi per rumpun, $\mathrm{BHR}=$ bobot biji hampa per rumpun, $\mathrm{BIR}=$ bobot biji isi per rumpun, $\mathrm{BSB}=$ bobot 1000 -biji dan $\mathrm{H}=$ bobot gabah per hektar. $\mathrm{KK}=$ koefisien korelasi berdasarkan uji lanjut DMRT dengan taraf kesalahan $5 \%$. 


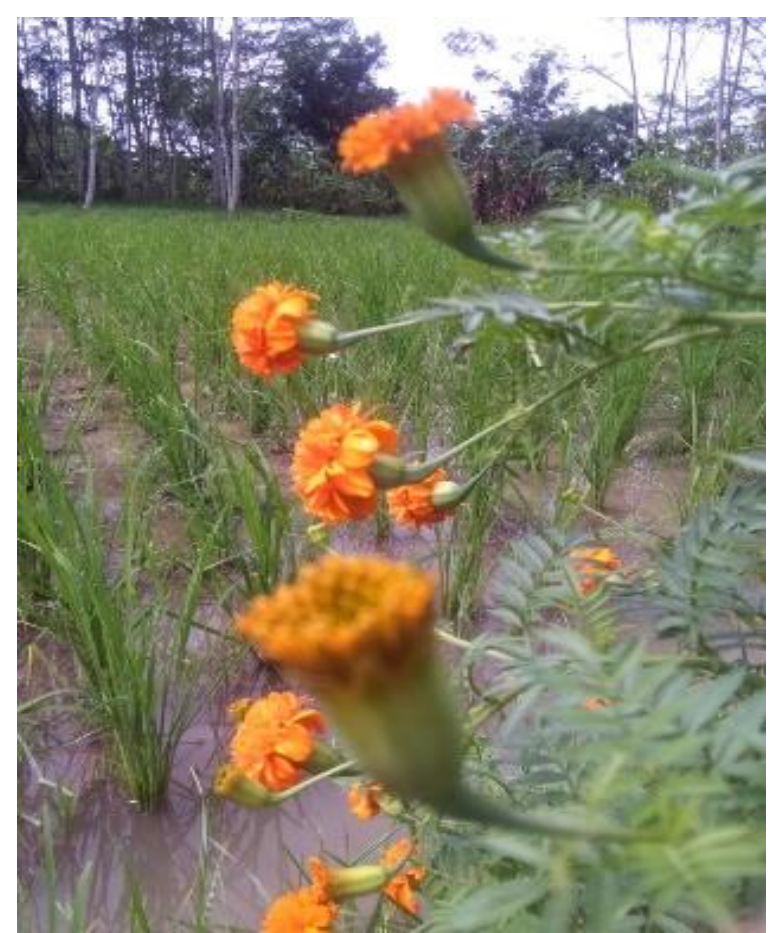

Gambar 2 Refugia bunga telekan (Dokumentasi penelitian dengan skala 1:5).

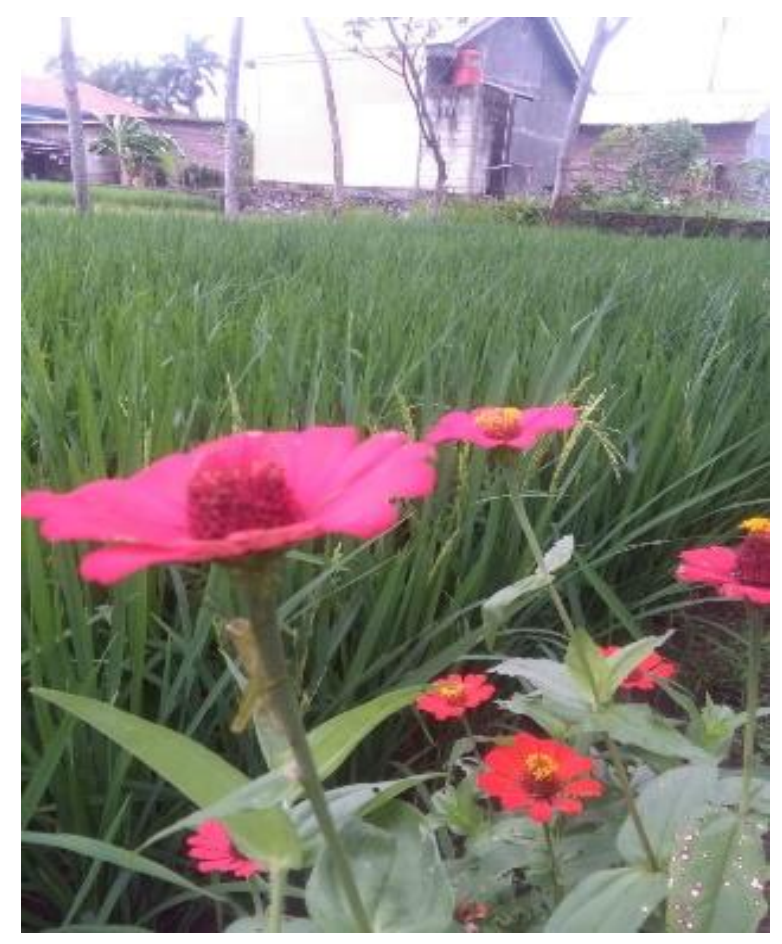

Gambar 3 refugia bunga kertas.

\section{KESIMPULAN}

Kelimpahan relatif artropoda dominan di lahan yang ditanami bunga kertas ialah Semut api (Solenopsis geminata) (11,07\%), Walang sangit (Leptocorisa oratorius) $(38,37 \%)$, dan Kupu-kupu Hypolimnas bolina $(0,17 \%)$ dengan nilai indeks keanekaragaman spesies masing-masing 3,25\%, 2,94\% dan 2,56\%. Kelimpahan relatif artropoda dominan di lahan yang ditanami bunga telekan ialah Serangga Cardiochilles (Cardiochiles philippinensis) (8,84\%), Belalang hijau (Oxya chinensis) (25,45\%), dan Penggerek batang padi kuning (Scirpophaga incertulas) (0,34\%) dengan nilai indeks keanekaragaman tergolong sedang. Penanaman bunga telekan memberikan hasil yang setara dengan perlakuan kontrol, yakni masing-masing 8,10 ton/ha dan 7,60 ton/ha, sedangkan pada penanaman bunbga kertas adalah 6,30 ton/ha.

\section{UCAPAN TERIMA KASIH}

Penulis mengucapkan terima kasih kepada Dekan Fakultas Pertanian Universitas Jenderal Soedirman atas ijin pelaksanaan penelitian dan Laboratorium Agroekologi atas fasilitasi peralatan dan dukungan selama penelitian hingga penulisan artikel ini.

\section{DAFTAR PUSTAKA}

Abidin Z, Laksono AS, Yanuwiadi B, Purnomo M. 2020. Refugia effect on arthropods in an organic paddy field in Malang District, East Java, Indonesia. Journal of Biodiversitas. 21(4): 1415-1421. https://doi.org/10.13057/biodiv/d210420

Adawiyah R, Aphrodyanti L, Aidawati N. 2020. Pengaruh Warna Bunga Refugia Terhadap Keanekaragaman Serangga Pada Pertanaman Tomat (Solanum lycopersicum). Jurnal Proteksi Tanaman Tropika. 3(2): 53-62

Addina L, Bagyo Y, Zulfaidah PG, Amin SL. 2013. Efek perpaduan beberapa tumbuhan liar di sekitar area pertanaman padi dalam menarik arthropoda musuh alami dan hama. Jurnal Elh-Hayah. 3(2): 71-81. https://doi.org/10.18860/ elha.v3i2.2612

Adiartayasa W, Wijaya IN. 2016. Serangan penggerek batang padi dan peran musuh alami dalam mengendalikan populasinya pada persawahan tanam serentak dan tidak serentak. Jurnal Agrotrop. 6(1): 19-25.

Allifah AN, Bagyo Y, Zulfaidah PG, Amin SL. 2013. Refugia sebagai mikrohabitat untuk meningkatkan peran musuh alami di lahan pertanian. Prosiding FMIPA Universitas Pattimura. 2(1): 113-115.

Altieri MA, Letourneau DK. 1982. Vegetation management and biological control in agroecosystems. 1, pp.405-430. https://doi.org/ 10.1016/0261-2194(82)90023-0

Arifin, Muhammad. 2012. Predator hama tanaman dan penular penyakit dermantitis. Jurnal Pengembangan Inovasi Pertanian. 5(1): 58-64.

Badan Pusat Statistik. 2017. Laju Pertumbuhan Penduduk Indonesia. [internet]. [diunduh pada tanggal 6 Desember 2017]. 
Tersedia: http:www.bps.go.id. Online diakses pada tanggal 6 Desember 2017.

Badan Pusat Statistik. 2015. Kebutuhan Konsumsi Beras Penduduk Indonesia. [internet]. [diunduh pada tanggal 6 Agustus 2018]. Tersedia pada: http:www.bp

Balai Perlindungan Tanaman Pangan Hortikultura dan Perkebunan Laboratorium Pengamatan Hama dan Penyakit Tanaman Banyumas. 2017. Penerapan Pengendalian Hama Terpadu (PHPHT)Skala Luas Padi Tahun 2017 Desa Tipar Kidul, Kec. Ajibarang, Kab. Banyumas. Laporan Akhir Kegiatan Penerapan Pengendalian Hama Terpadu (PHPHT) Skala Luas Padi Tahun 2017 Kelompok Tani "Sri Waluyo" Desa Tipar Kidul, Kecamatan Ajibarang, Kabupaten Banyumas.

Effendi BS. 2009. Strategi pengendalian hama terpadu tanaman padi dalam perspektif praktek pertanian yang baik (Good Agricultural Practices). Jurnal Pengembangan Inovasi. 2(1): 65-78.

Heong KL, Wong L, Reyas JHD. 2014. Addressing Planthopper Threats to Asian Rice Farming and Food Security: Fixing Insecticide Misuse. Rice Planthopphers pp. 65-76. https://doi.org/10.1007/ 978-94-017-9535-7_3

International Rice Research Institute. 2018. Insects (Pests and Diseases). [internet]. [diunduh pada tanggal: 11 Juli 2018]. Tersedia pada: http://www.knowledgebank.irri.org

Kartohardjono A. 2011. Penggunaan musuh alami sebagai komponen pengendalian hama padi berbasis ekologi. Jurnal Pengembangan Inovasi Pertanian. 4(1): 29-46.

Kurniawati N, Martono E. 2015. Peran Tumbuhan Berbunga Sebagai Media Konservasi Artropoda Musuh Alami. Jurnal Perlindungan Tanaman Indonesia 19(2): 53-59. https://doi.org/ 10.22146/jpti.16615

Khodijah. 2013. Keanekaragaman komunitas arthropoda predator tanaman padi yang diaplikasi bioinsektisida berbasis jamur entomopatogen di daerah rawa lebak Sumatera Selatan. Jurnal Lahan Sub Optimal. 2 (1): 43-49.

Kurniawati, Nia. 2015. Keragaman dan kelimpahan musuh alami hama pada habitat padi yang dimanipulasi dengan tumbuhan berbunga. Jurnal IImu Pertanian. 18(1): 31-36. https://doi.org/ 10.22146/ipas.6175

Lopes SF, Ramos MB, Almeida GR. 2017. The role of mountains as refugia for biodiversity in Brazilian Caatinga: conservationist implications. Tropical Conservervation Science 10: 1-12. https://doi.org/10.1177/1940082917702651

Maisyaroh W, Bagyo Y, Amin SL, Zulfaidah PG. 2012. Spatial And Temporal Distribution Of Natural
Enemies Visiting Refugia In A Paddy Field Area In Malang. Jurnal Agrivita.(34)1: 122-131. https:// doi.org/10.17503/Agrivita-2012-34-1-p067-074

Meyer RJ. 2006. Color Vision. Departemen of Entomology NC State University. [internet]. [diunduh pada Juni 2018]. Tersedia pada: http://www.cornell.go.id.

Muhibah TI, Leksono AS. 2015. Ketertarikan Arthropoda Terhadap Blok Refugia (Ageratum conyzoides L., Capsium frutescens L., Tagates ercta L) Dengan Aplikasi Pupuk Organik CairBiopestisida di Perkebunan Apel DesaPoncokusumo. Jurnal Biotropika. 3(3): 123-127.

Mustakim A, Leksono AS, Kusuma Z. 2014. Pengaruh blok refugia terhadap pola kunjungan serangga polinator di perkebunan apel Poncokusumo, Malang. Jurnal Natural. 2(3): 249-253. https:// doi.org/10.21776/ub.natural-b.2014.002.03.7

Parasappa HH, Narasa RG, Neelakanth. 2017. Rice insect pests and their natural enemies complexin different rice ecosystems of Cauvery command areas of Karnataka. Journal of Entomology and Zoology Studies. 5(5): 335-338.

Rahardjo B, Ikawati S, Prasdianata M, Tarno H. 2018. Effect of refugia on spatial and temporaldistribution of arthropods on rice agroecosystem (Oryza sativa Linn). Asian Journal Of Crop Science. 10(3): 134-140. 2018.134.140 https://doi.org/10.3923/ajcs.

Sakir IM, Desinta. 2018. Pemanfaatan Refugia dalam Meningkatkan Produksi Tanaman Padi Berbasis Kearifan Lokal. Jurnal Lahan Suboptimal. 7(1): 97-105. https://doi.org/10.33230/JLSO.7.1.2018 .367

Sari RP, Bagyo Y. 2014. Efek refugia pada populasi herbivora di sawah padi merah organik Desa Sengguruh, Kepanjen, Malang. Jurnal Biotropika. 2(1): 14-19.

Sumini, Samsul B. 2020. Keanekaragaman dan kelimpahan musuh alami ditanaman padi berdasarkan jarak dengan tanaman refugia. Jurnal Agrotek Tropika. 8(1): 177-184. ttps://doi.org/ 10.23960/jat.v8i1.3457

Sunariah F, Siti H, Yuanita W. 2016. Kelimpahan arthropoda karnivora di pertanaman padiratun di sawah lebak yang diaplikasikan bioinsektisida Bacillus thruringiensis. Jurnal Penelitian Sains. 18(1): 22-28.

Tridiptasari A, Agus D, Suhadi. 2017. Struktur dan komposisi komunitas serangga pada pertanian padi organik dan konvensional di Desa Sumber Ngepoh Kabupaten Malang. Jurnal Prodi Biologi. 3(6):1-11.

Triyono. 2017. Pengaruh pola tanama padi (Oryza sativa) kultivar Ciherang terhadap 
keanekaragaman jenis hama di kelompok tani sedyo maju Desa Jogotirto. Jurnal Prodi Biologi. 6(7): 416-422.

Visalakshmi V, Rao PRM, Satyanarayana HH. 2014. Impact of paddy cultivation systems on insect pest incidence. Journal of Crop and Weed. 10(1): 139-142.

Wardani FS, Amin SL, Bagyo Y. 2013. Efek blok refugia (Ageratum conyzoides, Ageratum houstonianum, Commelina diffusa) terhadap pola kunjungan arthropoda di perkebunan Apel Desa Poncokusumo. Jurnal Biotropika. 1(14): 134-139.
Wirastuti HA. 2016. Kemampuan efektivitas ekstrak daun kenikir dibandingkan dengan soffell aroma kulit jeruk sebagai repellent terhadap nyamuk aedes aegypti. Jurnal Penelitian Kesehatan Suara Forikes. 7(3):1-7.

Usyati N, Kurniawati N, Ruskandar A, Oco R. 2018. Populasi Hama dan Musuh Alamipada Tiga Cara Budidaya Padi Sawah di Sukama. Jurnal Agrikultura. 29(1): 35-42. https://doi.org/10.24198/ agrikultura.v29i1.16924 